\title{
COCAINE SMUGGLING BY HELP OF NARCO-SUBMARINES FROM SOUTH AMERICA TO EUROPE AND AFRICA: A PROVEN CASE - A LAST WAKE-UP CALL FOR CUSTOMS SERVICES AROUND THE WORLD
}

\begin{abstract}
The drug cartels of South America and organized crime have long been known to use semi-sub speedboats, Narco-Torpedoes and Narco-Submarines for smuggling cocaine from South America to Mexico and eventually to the United States of America. The drug trade is increasing strongly and organized crime is always looking for better and smarter ways to smuggle drugs into target countries. The story started as early as 1993 and eventually it started to be a case of chain manufacture of custom-built Narco-Submarines in 2007. Counter-measures in the Americas in the war on drugs are the use of Anti-Submarine Technology such as Submarine-hunter Aircrafts, Submarines and Coast Guard Ships. Now for the first time a NarcoSubmarine has been seized transporting more than 3000 Kilogram Cocaine to Spain. Are Europe's and Africa's Customs Administrations prepared? Are Europe's and North Africa's Coast Guard forces equipped and working together in order to seize Narco-Submarines from the Americas? This is the last wake up call for a newly emerging threat to Customs Services around the World. This capacity building and background paper investigates newspaper and official reports as well as scholarly papers on the development and evolution of Narco-Submarines in Middle and South America and the current use of Narco-Submarines in Middle and South America. In particular details on new developments in the increase of their use in smuggling attempts to North America are given. In particular itinvestigates and discusses in detail the case of a proven transAtlantic trip of a Narco-Submarine from South America to Europe in November 2019. In conclusion this paper calls for a higher awareness and better vigilance for this novel way of irregular naval warfare and drug smuggling from Southern America to Europe and Africa by help of Anti-Submarine technology such as Anti-Submarine Aircrafts, Anti-Submarine Naval Ships and the use of naval forces such as the Coast Guard in coordinated operations in Europe and Africa in order to combat global drug smuggling.
\end{abstract}

Key words: customs technology, law enforcement, smuggling, illicit drugs, smuggling technology, antisubmarine technology, submarine detection, capacity building, irregular naval warfare.

JEL Classification: E 26, F 14, K 33, K 34, Q 37.

\section{Carsten WEERTH,}

Senior Customs Officer

Main Customs Office Bremen,

Senior Lecturer

FOM Hochschule für Oekonomie

und Management

carsten.weerth@gmx.de

orcid.org/0000-0003-3702-8456

\section{Introduction}

Drug-smuggling techniques are applied in different modes by drug cartels and organized crime units in order to smuggle illicit drugs over borders: by help of low flying aircraft, speedboats, body-packers, utilizing fishing or merchant vessels (in hollow spaces or off board), using self-propelled semisubmersibles (SPSS) or Narco-torpedos, by help of the rip-off technique in bags of merchant containers such as banana containers, by reforming drugs into normal trade items, by simply smuggling them in hollow spaces in cars by help of drug tunnels and many other ways.

This paper investigates the use of Narco-Submarines in Middle and South America and investigates the case of a proven transAtlantic trip in November 2019.

\section{Overview about drug smuggling techniques}

Several drug smuggling techniques are used by the drug cartels globally.

- Well documented examples are:

- low flying aircraft that fly over borders underneath the radar;

- speedboats that run in safe distances along the shore and coastline in Middle America; 
- body-packers that ingest small packages of drugs;

- utilizing fishing, yachts or cargo/merchant vessels (in hollow spaces or off board);

- using self-propelled semisubmersibles (SPSS) or Narco-torpedos;

- using the rip-off technique in bags of merchant containers such as banana containers;

- reforming drugs into normal trade items;

- using hollow spaces in cars;

- using drug tunnels;

- using narco-drones;

- using mail, parcels and postal packages.

Many more techniques may apply. Smuggling techniques are normally well documented by the UN and its special illicit drug programs, by the national customs and police services (examples from Germany's Customs Service (Zoll, 2020a; Zoll, 2020b; Zoll, 2020c; Zoll, 2020d)) and even on Wikipedia (Illegal drug trade; Narco-submarine; Mule)). This paper focusses on the use of Narco-Submarines in the Americas and the potential crossing of the Atlantic Ocean and its implications.

\section{Evolution of Narco-Submarines in the Americas}

The so called Narco-Submarines were invented in South America by the drug cartels of Colombia in order to transport cocaine to the US. At first speedboats and semi-submersible speedboats and selfpropelled semisubmersibles (SPSS) or Narco-torpedoes (as early as 1993 (UNODC, 2012; Ramierez, Bunker, 2015: 9-14; Ramierez, Bunker, 2015: 38-45; Ramierez, Bunker, 2015: 29-32; Ramierez, Bunker, 2015: 33-37)), were mostly used until more and more sophisticated Narco-Submarines were developed up to 2010.

Three phases of Narco-Submarine development can be distinguished:

- Narco-sub Experimentation Phase: Early 1990ies through 2004,

- Narco-sub Prototyping Phase (Semi-Submersibles): 2005-2006,

- Narco-sub Standardization and Maturity Phase: 2007-2016 (Jacome Jarmillio, 2016).

And since then? Further developments are likely and this paper investigates a new development trans-oceanic smuggling travels from the Americas to Africa/Europe.

Hundreds of photos of Narco-Submarines and their varying design are well documented in the internet (Amicus, National Geographic Society, Nautica Report, Time Magazine, all online) and the scholarly literature on this matter (Ramierez, Bunker, 2015). The design of Narco-Submarines has also been explained by help of drawings and graphs (El pais; Sutton, 2019a).

\section{Importance of Maritime Smuggling in the Americas}

As of 2012 about 80 percent of all drugs were channelled from the Andean regions in maritime Smuggling to Honduras or Mexico (Ramierez, Bunker, 2015: 6-8). Up to 30 percent of this smuggling way is done by help of Narco-Submarines (Ramierez, Bunker, 2015). Data of seizures of Narco-Submarines has been published for 1993-2013 (Ramierez, Bunker, 2015: 38-45) with a peak of 20 seizures in 2009. Current data speak of a Narco-Submarine Epidemic in 2020 with 35 seizures in 2018 and 36 seizures in 2019 (Sutton, 2020). The Cocoa harvest has been very high in 2017-2018 - about three times higher than in 2008 (Sutton, 2020) and a lot of Cocaine is in Columbia that must be shipped away to its Markets in North America and Europe.

\section{Capacities of Narco-Submarines in the Americas}

Narco-Submarines are said to have a single load capacity of up to 8 000-10 000 Kilograms of illicit drugs per shipment (the biggest Narco-Submarine is said to be built for up to 200000 Kilograms or 200 Tons of drugs (Ramierez, Bunker, 2015)). They can travel semi-submersed or at underwater travel up to depths of 20 meters and are difficult to detect.

Some are having two motor systems (Diesel/Electro (Ramierez, Bunker, 2015)).

They mostly are travelling in coastal waters in the Middle Americas.

\section{Long-distance travels of Narco-submarines across the Atlantic Ocean? A legend?}

It has long been speculated that Narco-Submarines can also cross the Atlantic Ocean in order to make long-distance travels to Europe or North- or Western-Africa. It is a legend of Spanish law enforcement officers that a cartel member may have mentioned that way of smuggling.

In 2007 an extraordinary large Narco-Submarine was found on Columbia's Caribbean Coast and in 2014 a large Narco-Submarine was found in Guyana (South Americas) and both were speculated to be a model for a long distance run (Sutton, 2019a). 
But many have laughed at that idea as being nautically and technically not-feasible.

In December 2015 a Narco-Submarine was discovered in Brazil on the Atlantic coast, which only makes sense when the destination is Europe or Africa (Sutton, 2019a).

In November 2019 a Narco-Submarine was brought up off the coast of Spain transporting more than 3000 Kilograms of cocaine. This must be seen as a legend proven.

What are the consequences and implications? Are Europe's and Africa's customs offices, Coast Guards and Naval forces (Marines) equipped and prepared for such an unexpected naval warfare at their coasts?

\section{The proven case of a Narco-Submarine approach from the Americas to Europe in November 2019}

On 24 November 2019 a 22 meter long slender single motor Narco-Submarine was caught off Spain with more than 3000 Kilogram of Cocaine as load (The Guardian, 2019a; The Guardian, 2019b). Technically it was a so called low profile vessel (LPV) that is difficult to detect but cannot fully submerse (Sutton, 2019a). It was reported to have travelled from Guyana (South America) with a likely stop at Cape Verde (off the Coast of Africa) to Portugal and Spain (Sutton, 2019a). The mode of travel is uncertain. It is unknown if it has done the whole journey on its own or may have been towed or taken by a large ship for a long distance and then set on its own journey later. In 2006 a self-fabricated submarine (from Spain) was first attempting to bring cocaine ashore off Galicia/Spain but the cocaine was loaded on it near the coast (The Guardian, 2009; Sutton, 2019a). The design of this 2019 cocaine smuggling Narco-Submarine can be likened to a Narco-Submarine from South America that was caught in the Pacific Ocean off Columbia but with a longer design which was most likely due to more fuel tanks (Sutton, 2019b).

\section{Discussion}

The mode of narcotic drugs and cocaine smuggling is varying according to the geographical setting and the border problems. At the US-Mexican-Border low flying Aircraft, tunnels and drones are often in use. And also the method of drug smuggling through desert routes is applied.

In trans-Atlantic the preferred smuggling method is often by help of merchant vessels, body-packers in air-travel.

The rise of Narco-Submarines as mode of smuggling rose in the Americas from 2007 on where the newest and best-use design has been developed.

Up to 10000 Kilograms Cocaine can be shipped in one shipment in costal near waters (Goudar, 2019).

This has been one of the success-model of the cartels in the Americas in order to smuggle drugs from South Americas to Mexico and from there to the United States of America.

In three cases from 2007 to 2015 there were suspicions about Atlantic naval drug shipments by help of Narco-Submarines.

This proven case of a trans-Atlantic smuggling journey from South America to Europe in November 2019 shows the ability and practice of cocaine shipments by help of Narco-Submarines in great quantities (here 3 tons). It must be a wake-up call for the law-enforcement authorities in Africa and Europe. The customs authorities and coast guards must be aware of slowly travelling mostly submersed Narco-Submarines that are trying to land the remote coasts of Northern Africa or Portugal/Spain/France/Ireland/UK. Possibly the Narco-Submarines are not landing their load but re-distributing it on to Yachts or Fishing-Boats and Merchant Vessels off the coast. But vigilant European Coast Guard System must be aware of such a new threat and be able to detect such Narco-Submarines.

Submarine Hunters must be employed from the Naval Marines of the Countries in Question.

That also applies for flying Submarine Hunter aircrafts and the use of satellite technique.

The US is successfully employing its P-3 Orion Anti-Submarine (Hunting) Aircraft in the Americas (Sutton, 2020).

\section{Conclusions}

The War on drugs can only be won when all modes, techniques and ways of smuggling drugs into a country are known and understood. One way that is common in the Americas is the use of NarcoSubmarines. A new Narco-Submarine Epidemic is under way since 2018 when 35 Narco-Submarines were seized and in 2019, when 36 Narco-Submarines were seized. For the first time in November 2019 the trans-Atlantic smuggling of more than 3000 Kilograms of cocaine to from the Americas to Spain has been publicly well documented and widely discussed in the media and in law-enforcement circles. 
The new generation of Narco-Submarines is good enough to cross an entire ocean (either on their own power or being towed).

This is, this must be a wake-up call to all law enforcement and customs authorities in Europe and Africa. Apparently the drug cartels have found a vehicle for smuggling large quantities of drugs into another continent.

That raises the question of how well the law-enforcement side is prepared.

In the US the coast guard is openly combating the drug-speedboats and Narco-Submarines successfully.

But this problem has not been openly on the agenda in Europe and Africa, yet. Now it is.

\section{References:}

1. Amicus International Consulting. Narco-submarines: photo-gallery. Retrieved from: https://www.pinterest.de/amicusint/narco-submarines/ [in English].

2. Bureau for International Narcotics and Law Enforcement Affairs (2018). 2018 International Narcotics Control Strategy Report. Volume 1: Drug and Chemical Control. US Department of States. Retrieved from: https://www.state.gov/wp-content/uploads/2019/04/2018-INCSR-Vol.-I.pdf [in English].

3. Dinan, S. (2017). Drones become latest tool drug cartels use to smuggle drugs into U.S. The Washington Times. Retrieved from: https:/www.washingtontimes.com/news/2017/aug/20/mexican-drug-cartels-usingdrones-to-smuggle-heroi/ [in English].

4. Dunigan, M., Hoffmann, D., Chalk, P., Nichiporuk, B., DeLuca, P. (2012). Maritime Irregular Warfare / RAND - National Defense Research Institute, 139 p. Retrieved from: https://www.rand.org/content/dam/rand/ pubs/monographs/2012/RAND_MG1127.pdf [in English].

5. El pais. El submergible: photo-scheme. Retrieved from: https://www.elpais.com.co/elpais/archivos/ narco-submarinos.jpg [in English].

6. Fiegel, B. (2017). Narco-Drones: A New Way to Transport Drugs. Small Wars Journal. Retrieved from: https://smallwarsjournal.com/jrnl/art/narco-drones-a-new-way-to-transport-drugs [in English].

7. Fraser, D.M. (2012). Posture Statement of General Douglas M. Fraser, United States Air Force Commander, United States Southern Command Before the $112^{\text {th }}$ Congress House Armed Services Committee (March 6, 2012). Retrieved from: https://apps.dtic.mil/dtic/tr/fulltext/u2/a565018.pdf [in English].

8. Goudar, J. (2019). "Narco-Subs" Pose Underwater Threat for US, Colombia Authorities. InSight Crime. Retrieved from: https://www.insightcrime.org/news/brief/narco-subs-underwater-threat-us-colombia/ [in English].

9. Illegal drug trade. Wikipedia: the free encyclopedia. Retrieved from: https://en.wikipedia.org/wiki/ Illegal_drug_trade [in English].

10. Jacome Jaramillo, M. (2016). The Revolutionary Armed Forces of Colombia (FARC) and the Development of Narco-Submarines. Journal of Strategic Security, vol. 9, no. 1, pp. 49-69. Retrieved from: https://scholarcommons.usf.edu/cgi/viewcontent.cgi?referer=https://www.google.com/\&httpsredir=1\& article $=1509 \&$ context $=$ jss [in English].

11. Mule (Smuggling). Wikipedia: the free encyclopedia. Retrieved from: https:/en.wikipedia.org/wiki/ Mule_\%28smuggling\%29?wprov=sfla1 [in English].

12.Narco-submarine. Wikipedia: the free encyclopedia. Retrieved from: https://en.wikipedia.org/wiki/ Narco-submarine [in English].

13. National Geographic Society (2010). Cocaine Submarine Pictures: New Seizure Shows Advances. Retrieved from: https://www.nationalgeographic.com/news/2010/7/100713-cocaine-submarines-subssmuggling-drugs-world-crime-pictures/ [in English].

14.Nautica Report (2020). NarcoSub: i sommergibili della droga [NarcoSub: the drug submarines]. Retrieved from: https://www.nauticareport.it/dettnews.php?idx=6\&pg=5943 [in Italian].

15.Ramierez, B., Bunker, R.J. (eds.) (2015). Narco-Submarines: Specially Fabricated Vessels Used for Drug Smuggling Purposes / U.S. Army Foreign Military Studies Office. Claremont, 164 p. Retrieved from: http://fmso.leavenworth.army.mil/Collaboration/Interagency/Narco-Submarines.pdf [in English].

16.Stone, H. (2011). RawFeed: The evolution of the drug submarine. InSight Crime. Retrieved from: https://www.insightcrime.org/news/analysis/the-evolution-of-the-drug-submarine/ [in English].

17.Sutton, H.I. (2019a). Not unexpected: first Trans-Atlantic drug submarine. Forbes. Retrieved from: https://www.forbes.com/sites/hisutton/2019/11/26/big-deal-for-drug-smuggling-first-atlantic-narco-submarine/ \#2fb11e763a13 [in English].

18.Sutton, H.I. (2019b). Open source intelligence: Atlantic drug submarine may be related to pacific example. Forbes Retrieved from: https://www.forbes.com/sites/hisutton/2019/11/27/new-drug-submarinecaptured-in-spain-may-be-connected-to-pacific-example/\#579bed1f2453 [in English]. 
19.Sutton, H.I. (2020). U.S. coast guard could face a narco submarine epidemic in 2020. Forbes. Retrieved from: https://www.forbes.com/sites/hisutton/2020/01/07/why-america-could-continue-to-face-anarco-submarine-epidemic-in-2020/\#78ebe6d37369 [in English].

20.The Guardian (2009). Captured: drug-smuggling submarine built in garden shed. Retrieved from: https://www.theguardian.com/world/2009/dec/16/drugs-cocaine-smuggling-submarine-spain [in English].

21.The Guardian (2019a). Cocaine seized from "narco-submarine" in Spain was likely headed for UK. Retrieved from: https://www.theguardian.com/world/2019/nov/27/police-in-spain-find-three-tonnesof-cocaine-in-narco-submarine [in English].

22.The Guardian (2019b). Spanish police arrest suspected pilot of "narco-submarine". Retrieved from: https://www.theguardian.com/world/2019/dec/01/spanish-police-arrest-suspected-pilot-narco-submarine [in English].

23.UNODC (2012). Transnational Organized Crime in Central America and the Caribbean: a threat assessment. Vienna, 80 p. Retrieved from: https://www.unodc.org/documents/data-and-analysis/Studies/ TOC Central America and the Caribbean english.pdf [in English].

24.WCO (2019). Illicit Trade Report 2018. Retrieved from: http://www.wcoomd.org/-/media/wco/public/ global/pdf/topics/enforcement-and-compliance/activities-and-programmes/illicit-trade-report/itr_2018_ en.pdf?db=web [in English].

25.Zanetti, L. (2019). Silent Runner: photo gallery of narco-submarines. Time. Retrieved from: http://content.time.com/time/photogallery/0,29307,2061931 2260133,00.html [in English].

26.Zoll (2020a). 550 Gramm Kokain für Nürnberg abgefangen: Postsendung in Leipzig herausgefiltert, ein Tatverdächtiger in Untersuchungshaft [Caught 550 grams of cocaine for Nuremberg: Filtered out mail in Leipzig, a suspect in custody]. Retrieved from: https:/www.zoll.de/SharedDocs/Pressemitteilungen/DE/ Rauschgift/2020/z77_kokain_zfam.html [in German].

27.Zoll (2020b). Bodypacker von Zoll gestoppt: Rund ein Kilogramm Kokain im Körper [Body pack stopped by inches: Around a kilogram of cocaine in the body]. Retrieved from: https://www.zoll.de/SharedDocs/ Pressemitteilungen/DE/Rauschgift/2020/z84_bodypacker_m.html [in German].

28.Zoll (2020c). 27 Kilogramm Kokain im Reiseverkehr sichergestellt: Frankfurter Flughafenzoll nimmt zwei Männer vorläufig fest [27 kilograms of cocaine secured in travel: Frankfurt airport tariff temporarily arrests two men]. Retrieved from: https:/www.zoll.de/SharedDocs/Pressemitteilungen/DE/Rauschgift/2020/ z80_kokain_im_reiseverkehr.html [in German].

29.Zoll (2020d). Einfuhrschmuggel von 717 Kilogramm Kokain: Straßenverkaufswert des Rauschgifts beträgt mehr als 50 Millionen Euro [Import smuggling of 717 kilograms of cocaine: street sales value of the drug is more than 50 million euros]. Retrieved from: https://www.zoll.de/SharedDocs/Pressemitteilungen/DE/ Rauschgift/2020/z75_kokain_speisesalz.html [in German]. 


\title{
КОНТРАБАНДА КОКАЇНУ З ПІВДЕННОЇ АМЕРИКИ ДО ЄВРОПИ ТА АФРИКИ ЗА ДОПОМОГОЮ НАРКОСУБМАРИН: ДОВЕДЕНИЙ ВИПАДОК - ОСТАННІЙ СИГНАЛ ДЛЯ МИТНИХ СЛУЖБ У ВСЬОМУ СВІТІ
}

\author{
Карстен ВЕЕРТ, \\ головний офіцер митної служби \\ Головного митного управління міста Бремен, \\ стариий викладач \\ Університету прикладних наук у галузі економіки та управління \\ carsten.weerth@gmx.de \\ orcid.org/0000-0003-3702-8456
}

Уже давно відомо, що наркокартелі Південної Америки та злочинні організації використовують напівпідводні швидкохідні катери, наркоторпеди та наркосубмарини для контрабанди кокаїну з Південної Америки до Мексики, а потім і до Сполучених Штатів Америки. Обсяги торгівлі наркотиками значно зростають, організована злочинність завжди шукає найкращзі й хитрі способи контрабанди в изільові країни. Цей прочес розпочався ще в 1993 роиі $і$, як наслідок, призвів до виникнення ланиюга виробниитва спеціально розроблених наркосубмарин у 2007 роиі. Американські контрзаходи у війні проти наркотиків ие використання таких противодних технологій, як протичовнова авіачія, підводні човни та кораблі берегової охорони. Наразі зафіксовано перший випадок перехоплення наркосубмарини, яка транспортувала понад 3000 кілограмів кокаїну до Іспанії. Чи підготовлені митні адміністрації Європи та Африки? Чи споряджені належним чином і здатні співпрацювати сили берегової охорони Свропи та Північної Африки, щзоб захопити наркосубмарини з Америки? Це останній сигнал від нової загрози для митних служб у всьому світі. У изій публікації про нарощування потенціалу обігу наркотиків досліджено довідкові матеріали, газетні й офіиійні доповіді, а також наукові праці про розвиток та еволюиію наркосубмарин у Центральній i Південній Америці, їх сучасне використання. Зокрема, подано трунтовну інформацію про їх сучасний розвиток і використання у спробах контрабанди до Північної Америки. Досліджено й детально обговорено випадок доведеної трансатлантичної подорожі наркосубмарини з Південної Америки до Свропи в листопаді 2019 року. У підсумку дослідження автор закликає до більшої обізнаності й пильності щзодо иього нового способу ведення нерегулярної морської війни та контрабанди наркотиків із Південної Америки до Свропи й Африки за допомогою таких противодних технологій, як протичовнова авіація, протичовнові кораблі та використання військово-морських сил (наприклад, берегової охорони) у координованих операціях у Європі та Африці з метою боротьби зі світовою контрабандою наркотиків.

Ключові слова: митна технологія, правоохоронна діяльність, контрабанда, заборонені наркотики, технології контрабанди, протичовнові технології, виявлення підводних човнів, нарощування потенціалу, нерегулярна морська війна. 